\title{
Sustainable Activities of Universities: Experience from the Open Access Articles in the Economic Subject Area
}

\author{
Viktorija Šipilova \\ Dr.oec., Researcher, \\ The Institute of Humanities and Social Sciences, \\ Daugavpils University, Latvia
}

DOI: https://doi.org/10.36941/ajis-2020-0106

\section{Abstract}

Following to the global trends, the future role of sustainable universities will expand with the new focuses as, for example, entrepreneurial activities and Open Science. Entrepreneurial activities of universities provide possibilities to contribute to sustainability and Open Science is the tool for fast and simultaneous spread and exchange of the newest knowledge and good practices. This research focuses on three questions - how widespread economically oriented sustainable activities of universities are, which activities universities prefer as sustainable and economically oriented, and how often universities share such knowledge through Open Access articles. For the purpose, the author applies the monographic method, the logical analysis method, and the scientific induction method for the study of the selected Open Access articles about sustainable activities of universities in the economic subject area. Research findings indicate that the idea about sustainable and economically oriented activities of universities is widespread around the world and there are case studies from Europe, North America, Asia, and Africa. The analysis demonstrates differentiated accents in sustainable economically oriented activities of universities - globally accepted sustainability goals in economic sphere, entrepreneurial ecosystems, topicality of sustainability content in education for participants of labour market, new teaching approaches, transdisciplinary research, and university as sustainable and competitive participant at the market. Although, it is noteworthy to highlight that the exchange of knowledge and practice through Open Access articles in the relevant subject area is relatively modest and requires more attention from universities.

Keywords: university, sustainability, Open Access, economic subject area, sustainable activities, higher education for sustainability

\section{Introduction}

Following to the global trends, the future role of sustainable universities will expand with the new focuses as, for example, entrepreneurial activities and Open Science. The reasons for the new focuses come out from the global trends to incorporate sustainability principles in variety of areas fast and simultaneously. Universities demonstrate ability to act sustainably (e.g., Amaral et al., 2020). Additionally, the novel scientific opinion about sustainability fostered by not only natural sciences, but also by social sciences, humanities and arts (Shrivastava et al., 2020) widens possibilities of universities to act sustainably.

Mostly, the issue on how to balance economic and environmental interests is at the core of sustainability concept. Often, the limited access to the newest knowledge and insufficient exchange of 
good practices make the issue topical. Universities have core positions in realization of holistic approach what means to link interests of all stakeholders and society as a whole through realization of educational, research, and even entrepreneurial activities. Such approach allows universities providing the newest knowledge and examples of good trustable practices.

The topicality of knowledge economy, bio-economy, and “The European Green Deal” gives attention to the possible strong linkages between sustainable activities of universities in the economic sphere and sustainable development of regional and even global economy. In such case, universities are at the centre of the process due to their functions and resources. Scientists are sure that higher education has to support sustainable entrepreneurship (e.g., Fichter \& Tiemann, 2018; Wakkee et al., 2019). However, the questions on how to do this better still remain. Scientists provide rich scientific experience applying in-depth analysis for the different case studies (e.g., Fichter \& Tiemann, 2018; Probst et al., 2019; Wakkee et al., 2019). Such knowledge may be as catalyst for the fostering of economically oriented sustainable activities among universities with the positive effects on economy. Open Science and especially the articles in the Open Access may be the tool for such fast and trustable knowledge and experience exchange (e.g., see Mendez et al. (2020) about aims of Open Science). Fast and unlimited access to the trustable knowledge about economically oriented sustainable activities, especially realized by universities, fosters the spread of sustainability in all areas and in all sectors of economy.

This article aims to analyse the Open Access articles about sustainable activities of universities in the economic subject area. For the purpose, the article focuses on the Open Access articles selected with limitations - keywords, subject area and data source. As a result, it is possible to understand how widespread economically oriented sustainable activities of universities are, which activities universities prefer as sustainable and economically oriented, and how often universities share such knowledge through the Open Access articles. Answers for these questions provide the novelty of the research.

The research findings indicate that economically oriented sustainable activities of universities find wide realization and are presented in Europe, North America, Asia, and Africa. Thus, in general, the idea about universities as the agents encouraging sustainability in the economic sphere is widespread. In this regard, scientists devote attention to the case studies with the focus on economically oriented activities. Such sustainable and economically oriented activities of universities relate to the globally accepted sustainability goals in economic area, improvements of entrepreneurial ecosystems, actualizing sustainability content in education at labour market, launching transdisciplinary research and new teaching approaches, strengthening own competitiveness at market. Despite visible acceptance of the idea about sustainable and economically oriented activities of universities through realization of their direct and expanded functions, the exchange of the newest knowledge and good practices through the Open Access articles is not sufficient. As the analysis indicate, the articles in the Open Access devoted to economically oriented sustainable activities of universities are in little amount according to the data in Scopus database. However, such results depend on research limitations (keywords, subject area, and data source) as well.

The following paragraphs offer the literature review about sustainable economically oriented activities of universities, explanation of the data and methods applied, research results and conclusions with the answering on three questions set for the research.

\section{Literature Review}

Scientists understand sustainability as the main direction for the future of universities. Possibly, the more innovative approach for the future role of universities in sustainable development relates to the concept of "economically oriented sustainable university" (e.g., Beynaghi et al., 2016) with transdisciplinary approach to sustainability (e.g., Shrivastava, 2020).

The economics as the one of social sciences disciplines deserves special attention within the sustainability issue due to wide possibilities of, for example, bio-economy (as far as inter- and 
transdisciplinary research is crucial for sustainable development (e.g., Sedlacek, 2013)), knowledge economy (e.g. Karatzoglou, 2013), “The European Green Deal” (European Commission, 2019), "green entrepreneurs" (Fichter \& Tiemann, 2018). Additionally, scientists (e.g., Beynaghi et al., 2016) conclude that economically oriented university is able to foster creation and transfer of knowledge and technology, preparation of workforce and commercialization of research results for sustainability at the local, regional, and global levels through the social sciences and educational sciences. Scientific experience already demonstrates research findings that report about positive economic effects from universities activities in terms of teaching, entrepreneurship and, especially research activities (e.g., Guerrero et al., 2015).

Although, every initiative requires the necessity to balance interests of universities, society, business and regional needs (Guerrero et al., 2015) as well as high involvement and interest of students (e.g., Grindsted, 2016; Putri et al., 2020). Both, regions and students demonstrate interest in sustainability concept (e.g., Grindsted, 2016; Peer \& Stoeglehner, 2013). For example, Grindsted (2016) devotes attention to the interest of students to be a part of sustainable development processes. As Grindsted (2016) concludes, students believe that sustainable competences are crucial and will be necessary in the future labour market, especially in the certain spheres of economy. At the same time, regional sustainable development needs widening of the ways in which universities are involved in the development processes (e.g., Peer \& Stoeglehner, 2013).

The research findings indicate on the interest and positive effects from stakeholders involved in the sustainable development process. The important question relates to the exchange of experience and good practices among universities and other stakeholders. The Open Access articles may be the tool for fast and simultaneously spread of the newest knowledge and good practices (e.g., Mendez et al., 2020), as far as universities are able directly to contribute to this process. Vicente-Saez \& MartinezFuentes (2018) mention that Open Science may be driver for sustainable research and innovation. Additionally, scientists conclude that researchers have growing interest to publish in the Open Access both in natural sciences (e.g., Pourret et al., 2020) and in social sciences (e.g., Vuong et al., 2020).

However, as Karatzoglou (2013) indicates, the universities, which report about scientific findings in terms of sustainable development, need conceptualization and standardization of the reporting process for better adoption of practices and knowledge.

Thus, the issue requires attention and testing of which and how sustainable economically oriented activities of universities are shared through the Open Access articles in the economic subject area.

\section{Data and Method}

The author studies the Open Access articles about sustainable activities of universities in the economic subject area indexed in Scopus database. As a result of the analysis, the author detects the economic directions, where universities simultaneously act economically oriented and sustainably.

For the selection of the articles, the author employs keywords search tool in the Scopus database. The choice to use the Open Access articles, which are indexed in Scopus database, is grounded by the fact that Scopus is the largest expertly curated abstract and citation database of peer-reviewed literature (Elsevier, n.d.). The choice to use keywords as the search parameter for the selection of the Open Access articles is grounded by the fact that authors use keywords to highlight essence of research and indicate topicality of research questions.

Two keywords - "university" and "sustainability" - are the search parameters for the selection of the articles. Access type (Open Access) and subject areas (Economics, Econometrics and Finance; Business, Management and Accounting) are limitations for the selection of the articles. June 2020 is the search time for the articles for the analysis purposes. The author manually checks the selected articles for suitability for the research purpose and possible duplicates. After the check, a part of the articles remains out of the research frames. The articles excluded from the analysis are - duplicates, which are included in both subject areas (Economics, Econometrics and Finance; Business, 
Management and Accounting), articles with weak appropriateness to the research theme, conference articles, editorials, articles without author's keywords, articles not in English language.

The data from the Scopus database according to the searching parameters and limitations contain articles from 2006 to 2020 (June, due to search time). The Table 1 offers detailed information on the data collection and analysis.

Table 1. Data characteristics, selection criteria and benefits for the research purpose

\begin{tabular}{|c|c|c|}
\hline \multicolumn{2}{|c|}{ Data characteristics and selection criteria } & \multirow{2}{*}{$\begin{array}{l}\text { Benefits for the research purpose } \\
\text { The largest expertly curated abstract and citation database } \\
\text { of peer-reviewed literature (Elsevier n.d.). }\end{array}$} \\
\hline Data source & Scopus database & \\
\hline $\begin{array}{l}\text { Search } \\
\text { parameters }\end{array}$ & $\begin{array}{l}\text { Author keywords } \\
\text { "university" AND "sustainability" }\end{array}$ & $\begin{array}{l}\text { Keywords discover essence of the article, make article } \\
\text { more/less searchable, and highlight authors focus in } \\
\text { research. }\end{array}$ \\
\hline $\begin{array}{l}\text { Search } \\
\text { time }\end{array}$ & June 2020 & $\begin{array}{l}\text { The selected articles are published from } 2006 \text { (the start } \\
\text { point is offered by the Scopus database) to June } 2020 \text { (the } \\
\text { endpoint is chosen by the author for inclusion of the } \\
\text { newest studies). }\end{array}$ \\
\hline \multirow[t]{2}{*}{ Limitations } & Access type - Open Access & $\begin{array}{l}\text { Open Access - } 372 \text { documents from } 2006 \text { to } 2020 \text { (June) in } \\
\text { ALL subject areas }\end{array}$ \\
\hline & $\begin{array}{l}\text { Research subject areas - Economics, } \\
\text { Econometrics and Finance; } \\
\text { Business, Management and Accounting }\end{array}$ & $\begin{array}{l}\text { Economics, Econometrics and Finance } 11 \text { articles (1.2\% } \\
\text { from ALL subject areas); } \\
\text { Business, Management and Accounting } 12 \text { articles (1.3\% } \\
\text { from ALL subject areas). }\end{array}$ \\
\hline $\begin{array}{l}\text { Manual } \\
\text { check }\end{array}$ & $\begin{array}{l}\text { Check for suitability for the research } \\
\text { purpose }\end{array}$ & $\begin{array}{l}\text { Articles excluded from the analysis - duplicates included } \\
\text { in both subject areas (each article is included in the } \\
\text { analysis only one time), articles with weak appropriateness } \\
\text { to the research theme, conference articles, editorials, } \\
\text { articles without authors keywords, and articles written not } \\
\text { in English language. }\end{array}$ \\
\hline $\begin{array}{l}\text { Data for the } \\
\text { analysis }\end{array}$ & $\begin{array}{l}\text { Nine Open Access articles in subject } \\
\text { areas Economics, Econometrics and } \\
\text { Finance; } \\
\text { Business, Management and Accounting }\end{array}$ & $\begin{array}{l}\text { Articles published in } 2013,2014,2016,2018,2019 \text {, and 2020, } \\
\text { thus providing the newest viewpoints. }\end{array}$ \\
\hline $\begin{array}{l}\text { Journals of } \\
\text { the selected } \\
\text { articles }\end{array}$ & $\begin{array}{l}\text { Amfiteatru Economic; } \\
\text { Entrepreneurship and Sustainability } \\
\text { Issues; } \\
\text { Small Business Economics; } \\
\text { Mediterranean Journal of Social } \\
\text { Sciences; } \\
\text { Asian Social Science; } \\
\text { Journal of Cleaner Production; } \\
\text { Research Policy. }\end{array}$ & $\begin{array}{l}\text { Open Access articles published in seven journals. } \\
\text { Four journals }-1^{\text {st }} \text { quartile. } \\
\text { One journal }-2^{\text {nd }} \text { quartile. } \\
\text { Two journals - coverage discontinued in Scopus. } \\
\text { Journals subject areas - Business, Management and } \\
\text { Accounting; Economics, Econometrics and Finance; } \\
\text { Decision Sciences; Arts and Humanities; Social Sciences; } \\
\text { Environmental Science; Engineering; Energy. }\end{array}$ \\
\hline
\end{tabular}

Source: compiled by the author using data from Scopus database.

For the purpose of the article, the author applies the monographic method, the logical analysis method, and the scientific induction method. The next section presents the research results.

\section{The Research Results}

Universities consider their participation in sustainable development from two points of view. First, university as educational and research institution may develop in a sustainable manner by itself; second, university's sustainable-oriented activities may provide positive and long-term effects on sustainable development in economy, society, and environment at regional level and even global level. Both variants may develop simultaneously.

The articles analysed within the research are published during the last seven years in journals with subject areas in natural sciences, social sciences, arts and humanities, what corresponds with the 
scientific thought about necessity to develop sustainability concept from the transdisciplinary perspective (e.g., Shrivastava et al., 2020). The most of them relates to the $1^{\text {st }}$ quartile in Scopus dabase.

The author organizes the research results in the Table 2 and indicates sustainability accents, the role of universities, the economic context and the source. It is noteworthy that nine Open Access articles selected for the research purpose demonstrate wide and even innovative understanding of sustainable universities in the economic context. The Table 2 offers the analysis with highlights.

Table 2. Sustainability accents, the role of universities, the economic context and the source of the selected Open Access articles

\begin{tabular}{|c|c|c|c|}
\hline Sustainability Focus & University Role & Economic Context & \begin{tabular}{|l|} 
Source \\
\end{tabular} \\
\hline \multirow{3}{*}{$\begin{array}{l}\text { SUSTAINABLE UNIVERSITY } \\
\text {-ESD goals } \\
\text {-GreenMetrics criteria } \\
\text {-being competitive in a } \\
\text { private sector }\end{array}$} & $\begin{array}{l}\text { To be a sustainable university } \\
\text { through realizing "Education for } \\
\text { sustainable development goals" } \\
\text { (ESD goals) } \\
\end{array}$ & \begin{tabular}{|l|} 
Professional behaviour of young \\
people after studying at Business and \\
Tourism Faculty - Bucharest \\
University of Economic Studies \\
\end{tabular} & $\begin{array}{l}\text { Maiorescu et } \\
\text { al. (2020) }\end{array}$ \\
\hline & $\begin{array}{l}\text { To create a sustainable university } \\
\text { by following five GreenMetric } \\
\text { criteria - Water, Transport, } \\
\text { Positioning and Infrastructure, } \\
\text { Education and Research, Energy } \\
\text { and Climate Change } \\
\end{array}$ & $\begin{array}{l}\text { Water, Transport, Positioning and } \\
\text { Infrastructure, Education and } \\
\text { Research, Energy and Climate } \\
\text { Change are the significant elements } \\
\text { of economic activities in every sector } \\
\text { of economy }\end{array}$ & $\begin{array}{l}\text { Șerban et al. } \\
(2020)\end{array}$ \\
\hline & $\begin{array}{l}\text { To be a sustainable private } \\
\text { university through quality } \\
\text { assurance supported by } \\
\text { motivation of stakeholders }\end{array}$ & $\begin{array}{l}\text { Private universities, which want to } \\
\text { remain competitive and become a } \\
\text { market leaders in the educational } \\
\text { sector }\end{array}$ & $\begin{array}{l}\text { Tang \& } \\
\text { Hussin } \\
(2013)\end{array}$ \\
\hline \multirow{3}{*}{$\begin{array}{l}\text { EDUCATION/RESEARCH } \\
\text {-engineering education with } \\
\text { sustainability content } \\
\text {-teaching of sustainable } \\
\text { entrepreneurship } \\
\text { - inter- and transdisciplinary } \\
\text { sustainability research }\end{array}$} & $\begin{array}{l}\text { Pedagogical approaches to } \\
\text { Engineering education with } \\
\text { accent on sustainability content } \\
\text { for providing conceptual } \\
\text { knowledge for sustainable design }\end{array}$ & $\begin{array}{l}\text { Engineers/designers will have lasting } \\
\text { economic impacts (p.1) }\end{array}$ & $\begin{array}{l}\text { Watson et } \\
\text { al. (2016) }\end{array}$ \\
\hline & $\begin{array}{l}\text { Passive and active teaching } \\
\text { methods of sustainable } \\
\text { entrepreneurship }\end{array}$ & $\begin{array}{l}\text { Sustainable entrepreneurial } \\
\text { intentions of students of the } \\
\text { department of Business and } \\
\text { Management }\end{array}$ & Fatoki (2019) \\
\hline & $\begin{array}{l}\text { Scientists devote attention to } \\
\text { solving the problems (as poverty, } \\
\text { development, environment) } \\
\text { applying inter- and } \\
\text { transdisciplinary research } \\
\end{array}$ & $\begin{array}{l}\text { University as research provider for } \\
\text { the shift in economic development } \\
\text { towards sustainability concept }\end{array}$ & $\begin{array}{l}\text { Rau et al. } \\
(2018)\end{array}$ \\
\hline \multirow{2}{*}{$\begin{array}{l}\text { ENTREPRENEURIAL } \\
\text { ECOSYSTEM } \\
\text {-university campus as } \\
\text { entrepreneurial ecosystem } \\
\text {-universities direct inputs to } \\
\text { sustainable entrepreneurial } \\
\text { ecosystem }\end{array}$} & $\begin{array}{l}\text { Establishing of campus shopping } \\
\text { centre in one University of } \\
\text { Technology in South Africa as } \\
\text { innovative campus problem } \\
\text { solving }\end{array}$ & $\begin{array}{l}\text { Combination of different businesses } \\
\text { - education and shopping/catering } \\
\text { for university community. } \\
\text { Understanding of university } \\
\text { community as customers of } \\
\text { sustainable services. }\end{array}$ & $\begin{array}{l}\text { Chinomona } \\
\text { et al. (2014) }\end{array}$ \\
\hline & $\begin{array}{l}\text { University contributes to the } \\
\text { improvements of sustainable } \\
\text { entrepreneurial ecosystem and } \\
\text { provides direct inputs (e.g., spin- } \\
\text { offs) }\end{array}$ & \begin{tabular}{|l|} 
Contribution to the sustainable \\
economic development of regions \\
through the positive knowledge \\
spillovers gained from the support of \\
sustainable entrepreneurial \\
ecosystem
\end{tabular} & $\begin{array}{l}\text { Wagner et } \\
\text { al. (2019) }\end{array}$ \\
\hline $\begin{array}{l}\text { of sustainability } \\
\text { degree title }\end{array}$ & $\begin{array}{l}\text { Universities may act as } \\
\text { innovators by making visible } \\
\text { sustainability content in their } \\
\text { degree titles }\end{array}$ & $\begin{array}{l}\text { The sustainability content, which is } \\
\text { visible in degree title, as } \\
\text { competitiveness factor at labour } \\
\text { market }\end{array}$ & $\begin{array}{l}\text { Zorio-Grima } \\
(2020)\end{array}$ \\
\hline
\end{tabular}

Source: compiled by the author using Maiorescu et al. (2020), Șerban et al. (2020),Tang \& Hussin (2013), Watson et al. (2016), Fatoki (2019), Rau et al. (2018), Chinomona et al. (2014), Wagner et al. (2019), Zorio-Grima (2020). 
There is possible to highlight four different sustainability accents considered within the selected articles about sustainable universities in the economic subject area - sustainable university as the aim of the higher education institution, education and research for solving the economic issues, improvements in entrepreneurial ecosystems and labour market needs.

The highlights indicate that stakeholders understand the role of universities in the strengthening and spreading the sustainability concept widely and even innovatively. Universities are able to provide positive effects on economy, for example, preparation of workforce with sustainable competences and knowledge, creation of new sustainability content, approbation and improvement of the existing sustainable practices, support for sustainable business, practice of sustainable research etc.

If one considers economy as the space for sustainable activities of universities, it is possible to indicate some motivational as well as hindering factors for the sustainable economic development taking into account the considered Open Access articles. Realization of the ESD goals (e.g., Maiorescu et al., 2020), solving the "real world problems" (e.g., Rau et al., 2018), development according to the GreenMetrics criteria (e.g., Șerban et al., 2020), profit-interests of private educational institutions (e.g., Tang \& Hussin, 2013), participation in and support of sustainable entrepreneurial activities (e.g., Fatoki, 2019; Wagner et al. 2019), ensuring sustainable research (e.g., Rau et al., 2018), and predicting labour market needs (e.g., Zorio-Grima, 2020) may be understood as motivational factors for sustainable development in economic sphere ensured by universities. The fact that the biggest share of research about sustainable activities of universities in the economic subject area and indexed in Scopus database during the period analysed is not published in the Open Access may be understood as significant hindering factor, because this may slow down exchange of the newest knowledge and even innovative ideas.

The research results demonstrate the interest of universities to act sustainably in the economic sphere and highlight the clear vision of possible ways to be involved in the process. Despite the research limitations (keywords, access type, and research subject area), the overall motivation of universities and their possibilities to act sustainably in the economic sphere are visible.

\section{Conclusions}

The purpose of the article is to analyse the Open Access articles about sustainable activities of universities published in the economic subject area and indexed in Scopus database. It is noteworthy that studies about sustainable activities of universities published in the economic subject area are in lesser amount than in other sustainability issues. There are nine Open Access articles from the Scopus database suitable for the analysis according to the selection parameters (keywords, access type, and subject area) and manual check results.

The current study provides answers to the following questions - how widespread economically oriented sustainable activities of universities are, which activities universities prefer as sustainable and economically oriented, and how often universities share such knowledge through the articles in the Open Access.

The research results allow concluding that knowledge about necessity and usefulness of the economically oriented sustainable activities of universities are widespread. The geographic data of case studies and affiliations of authors indicate this. The selected articles demonstrate that scientists from Europe, Africa, Asia, and North America share experience and ideas. Scientists analyse the case studies from Germany, Romania, Spain, United States, South Africa, and Malaysia, as well as discuss about conceptual issues of sustainability without any concrete case study.

The answer to the question about preferable sustainable and economically oriented activities of universities is positive as well. The articles analysed allow concluding that the case studies and innovative ideas of scientists relate to both universities traditional functions and their expansion. For example, scientists offer inter- and transdisciplinary sustainability research, university campus as entrepreneurial ecosystem, and visibility of sustainability content in degree title what requires expansion or development of usual functions of universities. Other considered studies offer to follow 
widely recognized aims for the sustainable development and to apply evaluation metrics, to develop teaching approaches and content and directly to contribute to the entrepreneurial ecosystems.

Little amount of the Open Access articles about sustainable universities in the economic subject area indexed in Scopus database calls for the deeper involvement of universities in the process of spread and exchange of knowledge and good practices. Fast and simultaneous exchange of research results and good practices may be as the key element for strengthening motivation among universities to act sustainably and to widen their sustainable activities, especially towards the economic issues.

\section{References}

Amaral, A.R., Rodrigues, E., Gaspar A.R., \& Gomes, A. (2020). A review of empirical data of sustainability initiatives in university campus operations. Journal of Cleaner Production, 250 (2020), 119558. https://doi.org/10.1016/j.jclepro.2019.119558

Beynaghi, A., Trencher, G., Moztarzadeh, F., Mozafari, M., Maknoon, R., \& Filho, W.L. (2016). Future sustainability scenarios for universities: moving beyond the United Nations Decade of Education for Sustainable Development. Journal of Cleaner Production, 112, 3464-3478. http://dx.doi.org/10.1016/j.jclepro.2015.10.117

Chinomona, E., Maziriri, E., \& Moloi, K.C. (2014). Corporate Entrepreneurship with Innovation in Mind in one University of Technology in South Africa. Mediterranean Journal of Social Science, 5(23), 20-29. Doi:10.5901/mjss.2014.v5n23p2o

Elsevier. (n.d.). Scopus. About. Retrieved from https://blog.scopus.com/about

European Commission. (2019). The European Green Deal sets out how to make Europe the first climate-neutral continent by 2050, boosting the economy, improving people's health and quality of life, caring for nature, and leaving no one behind. Retrieved from https://ec.europa.eu/commission/presscorner/detail/e\%2on/ip_19_6691

Fatoki, O. (2019). Sustainability orientation and sustainable entrepreneurial intentions of university students in South Africa. Entrepreneurship and Sustainability Issues, 7(2), 990-999. http://doi.org/10.9770/jesi.2019.7.2(14)

Fichter, \& K., Tiemann, I. (2018). Factors influencing university support for sustainable entrepreneurship: Insights from explorative case studies. Journal of Cleaner Production, 175 (2018), 512e524. https://doi.org/10.1016/j.jclepro.2017.12.031

Grindsted, T.S. (2016). Regional planning, sustainability goals and the mitch-match between educational practice and climate, energy and business plans. Journal of Cleaner Production, 171, 1681-1690. http://dx.doi.org/10.1016/j.jclepro.2016.09.197

Guerrero, M., \& Cunningham, J.A., \& Urbano, D. (2015). Economic impact of entrepreneurial universities' activities: An explanatory study of the United Kingdom. Research Policy, 44, 748-764. http://dx.doi.org/10.1016/j.respol.2014.10.0o8

Karatzoglou, B. (2013). An in-depth literature review of the evolving roles and contributions of universities to Education for Sustainable Development. Journal of Cleaner Production, 49, 44-53. http://dx.doi.org/10.1016/j.jclepro.2012.07.043

Maiorescu, I., Sabou, G.C., Bucur, M, \& Zota, R.D. (2020). Sustainability Barriers and Motivations in Higher Education - A Students' Perspective. Amfiteatru Economic, 22(54), 362-375.

Mendez, E., Lawrence, R., MacCallum, C.J., Moar, E., together with all the members of the Open Science Policy Platform. (2020). Progress on Open Science: Towards a Shared Research Knowledge System. Final Report of the Open Science Policy Platform. DOI: 10.2777/00139. Retrieved from https://ec.europa.eu/research/openscience/pdf/ec_rtd_ospp-final-report.pdf

Peer, V., \& Stoeglehner, G. (2013). Universities as change agents for sustainability - farming the role of knowledge transfer and generation in regional development processes. Journal of Cleaner Production, 44, 85-95. http://dx.doi.org/10.1016/j.jclepro.2012.12.003

Pourret, O., Irawan, D.E., Tennant, J.P., Hursthouse, A., \& van Hullebusch, E.D. (2020). The growth of open access publishing in geochemistry. Results in Geochemistry (100001), In Press. https://doi.org/10.1016/j.ringeo.2020.100001

Probst, L., Bardach, L., Kamusingize, D., Templer, N., Ogwali, H., Owamani, A., Mulumba, L., Onwonga, R., \& Adugna, B.T. (2019). A transformative university learning experience contributes to sustainability attitudes, skills and agency. Journal of Cleaner Production, 232, (2019), 648e656. https://doi.org/10.1016/j.jclepro.2019.05.395

Putri, N.T., Amrina, E., \& Nurnaeni, S. (2020). Students' Perceptions of the Implementation of Sustainable Campus Development Based on Landscape Concepts at Andalas University. Procedia Manufacturing, 43(2020), 255262, 17th Global Conference on Sustainable Manufacturing. DOI: 10.1016/j.promfg.2020.02.150 
Rau, H., Goggins, G., \& Fahy, F. (2018). From invisibility to impact: Recognising the scientific and societal relevance of interdisciplinary sustainability research. Research Policy, $47 \quad$ (2018) $266-276$. https://doi.org/10.1016/j.respol.2017.11.005

Sedlacek, S. (2013). The role of universities in fostering sustainable development at the regional level. Journal of Cleaner Production, 48, 74-84. http://dx.doi.org/10.1016/j.jclepro.2013.01.029

Șerban, E.C., Hristea, A.M., Curea, Ș.C. \& Crețu, R.F. (2020). Sustainable Universities, from Indifference to Joint Action - A Panel Data Analysis. Amfiteatru Economic, 22(54), 376-39o.

Shrivastava, P., Stafford Smith, M., O’Brien, K., \& Zsolnai L. (2020). Transforming Sustainability Science to Generate Positive Social and Environmental Change Globally. One Earth, 2(2020), 329-340. https://doi.org/10.1016/j.oneear.2020.04.010

Tang, S.F., \& Hussin, S. (2013). Advancing Sustainability in Private Higher Education through Quality Assurance: A Study of Two Malaysian Private Universities. Asian Social Science, 9(11), $270-279$. http://dx.doi.org/10.5539/ass.v9n11p270

Vuong T.-T., Ho M.-T., Nguyen, M.-H., Nguyen, T.-H.T., Nguyen, T.-D., Nguyen, T.-L., Luong, A.P., \& Vuong, Q.H. (2020). Adopting open access in the social sciences and humanities: evidence from a developing nation. Heliyon, 6(2020), e04522. https://doi.org/10.1016/j.heliyon.2020.e04522

Wagner, M., Schaltegger, S., Hansen, E.G., \& Fichter K. (2019). University-linked programmes for sustainable entrepreneurship and regional development: how and with what impact? Small Business Economics (2019). https://doi.org/10.1007/s11187-019-00280-4

Wakkee, I., van der Sijdeb, P., Vaupell, C., \& Ghuman, K. (2019). The university's role in sustainable development: Activating entrepreneurial scholars as agents of change. Technological Forecasting E Social Change, 141 (2019), 195-205. https://doi.org/10.1016/j.techfore.2018.10.013

Watson, M.K., Pelkey, J., Noyes, C., \& Rodgers, M. (2016). Assessing Impacts of a Learning-Cycle-Based Module on Students' Conceptual Sustainability Knowledge using Concept Maps and Surveys. Journal of Cleaner Production, 133, 544-556. https://doi.org/10.1016.j.clepro.2016.04.063 View Open Manuscript. Version of Record. Retrieved from https://www.sciencedirect.com/science/article/pii/So959652616303316

Zorio-Grima, A. (2020). Driving factors for having visibility of sustainability contents in university degree titles. Journal of Cleaner Production, 242 (2020), 114746, https://doi.org/10.1016/j.jclepro.2018.10.344 